P-ISSN 2580 - 7781

E-ISSN 2615 - 3238

\title{
PENGARUH RETURN ON ASSETS (ROA), RETURN ON EQUITY (ROE), DAN NET PROFIT MARGIN (NPM) TERHADAP HARGA SAHAM PADA PERUSAHAAN FARMASI YANG TERDAFTAR DI BURSA EFEK INDONESIA (BEI)
}

\section{THE EFFECT OF RETURN ON ASSETS (ROA), RETURN ON EQUITY (ROE), AND NET PROFIT MARGIN (NPM) ON STOCK PRICES IN PHARMACEUTICAL COMPANIES LISTED ON THE IDX}

\author{
Gusnar Mustapa $^{1)}$, Hendy Hermawan ${ }^{2)}$, Yessi Raraswati ${ }^{3)}$ \\ ${ }^{1,2,3}$ Jurusan Akuntansi, STIE Indocakti Malang \\ ${ }^{1}$ Email : gusnar.mustapa@gmail.com
}

\begin{abstract}
ABSTRAK
Penelitian ini bertujuan untuk menganalisis pengaruh Return On Assets (ROA), Return On Equity (ROE), Net Profit Margin (NPM) baik secara parsial maupun secara simultan terhadap Harga Saham dan pengaruh paling dominan antara Return On Assets (ROA), Return On Equity (ROE), Net Profit Margin (NPM) pada perusahaan Farmasi yang terdaftar di BEI. Penelitian ini dilakukan dengan menggunakan data sekunder. Teknik sampel yang digunakan adalah purposive sampling. Dari sepuluh perusahaan, hanya diambil lima perusahaan, karena memiliki laporan keuangan secara lengkap di tahun 2015-2019. Metode analisis yang digunakan adalah analisis regresi linier berganda yang dilakukan dengan SPSS. Hasil penelitian ini disimpulkan bahwa; 1) Secara parsial, Variabel Return On Assets (ROA) berpengaruh negatif dan signifikan terhadap harga saham pada perusahaan farmasi; 2) Secara parsial, Variabel Return On Equity (ROE) berpengaruh positif dan signifikan terhadap harga saham pada perusahaan farmasi; 3) Secara parsial, variabel Net Profit Margin (NPM) berpengaruh positif dan signifikan terhadap harga saham pada perusahaan farmasi; 4) Secara simultan, variabel Return On Assets (ROA), Return On Equity (ROE), dan Net Profit Margin (NPM) berpengaruh secara signifikan terhadap variabel terikat Harga Saham pada perusahaan farmasi yang terdaftar di BEI Tahun 2015 - 2019.
\end{abstract}

Kata kunci: Harga saham, Return On Assets (ROA), Return On Equity (ROE) dan Net Profit Margin (NPM)

\footnotetext{
ABSTRACT

This study aims to analyze the effect of Return On Assets (ROA), Return On Equity (ROE), Net Profit Margin (NPM) either partially or simultaneously on Stock Prices and the most dominant influence between Return On Assets (ROA), Return On Equity. (ROE), Net Profit Margin (NPM) in pharmaceutical companies listed on the IDX. This research was conducted using secondary data. The sample technique used was purposive sampling. Of the ten companies, only five were taken, because they had complete financial reports for 2015-2019. The analytical method used is multiple linear regression analysis performed with SPSS. The results of this study concluded that 1) Partially, the variable Return on Assets (ROA) has a negative and significant effect on stock prices in pharmaceutical companies. 2) Partially, the variable Return On Equity (ROE) has a positive and significant effect on stock prices in pharmaceutical companies. 3) Partially, the Net Profit Margin (NPM) variable has a positive and significant effect on stock prices in pharmaceutical companies. 4) Simultaneously, the variable Return On Assets (ROA), Return On Equity (ROE), and Net Profit Margin (NPM) has a significant effect on the
} 
P-ISSN 2580 - 7781

E-ISSN $2615-3238$

dependent variable Stock Prices in pharmaceutical companies listed on the IDX in 2015 2019.

Keywords: Stock Prices, Return On Assets (ROA), Return On Equity (ROE) and Net Profit Margin (NPM)

\section{PENDAHULUAN}

Perkembangan pasar modal saat ini menunjukkan perkembangan yang penting bagi perekonomian Indonesia. Hal ini terjadi karena semakin meningkatnya minat masyarakat untuk berinvestasi di pasar modal, berkembangnya pengetahuan masyarakat tentang pasar modal, jumlah perusahaan yang terdaftar di pasar modal dan dukungan pemerintah melalui kebijakan berinvestasi. Kegiatan investasi saham diharapkan menghasilkan keuntungan bagi para pelakunya, dan harga saham mencerminkan perubahan minat investor terhadap saham tersebut.

Pengaruh faktor fundamental perusahaan terhadap perubahan harga saham dapat diketahui dengan melakukan analisis fundamental. Analisis ini merupakan analisis yang berhubungan dengan faktor fundamental perusahaan yang ditunjukkan dalam laporan keuangan perusahaan. Menurut Darmadji dan Fakhruddin (2011) Analisis fundamental merupakan salah satu cara untuk melakukan penilaian saham dengan mempelajari atau mengamati berbagai indikator yang terkait dengan kondisi makro ekonomi dan kondisi industri suatu perusahaan hingga berbagai indikator keuangan dan manajemen perusahaan.

Dalam penelitian ini faktor fundamental yang digunakan oleh penulis adalah dari kelompok rasio profitabilitas di antaranya adalah Return On Assets (ROA), Return On Equity (ROE), dan Net Profit Margin (NPM). Mengingat tujuan investor berinvestasi adalah mencari keuntungan berupa capital gain dan deviden, maka analisis fundamental melalui rasio Return On Assets (ROA), Return On Equity (ROE), dan Net Profit Margin (NPM) dapat memberikan sinyal kepada investor untuk berinvestasi.

Return On Assets (ROA) menunjukkan kemampuan dalam perusahaan menghasilkan laba atas aktiva yang dipergunakan. Lukman (2009) menyatakan pentingnya pengukuran rasio ini didalam suatu perusahaan dimana semakin tinggi rasio return on assets, semakin baik keadaan suatu perusahaan. Return On Equity 
P-ISSN 2580 - 7781

E-ISSN 2615 - 3238

(ROE) menunjukkan kemampuan suatu perusahaan dalam menghasilkan laba untuk kesejahteraan pemilik modal atau investor. Menurut Fahmi (2012), Return On Assets (ROA) adalah rasio yang digunakan untuk mengkaji sejauh mana suatu perusahaan mempergunakan sumber daya yang dimiliki untuk mampu memberikan laba atas ekuitas yang dimiliki. Dan Net Profit Margin (NPM) menggambarkan kemampuan perusahaan untuk menghasilkan laba bersih yakni laba bersih setelah pajak yang dibandingkan dengan penjualan bersih. Menurut Hanafi dan Halim (2012), Net Profit Margin merupakan rasio yang menghitung sejauh mana kemampuan perusahaan menghasilkan laba bersih pada tingkat penjualan tertentu. Semakin besar NPM, maka kinerja perusahaan akan semakin produktif, sehingga akan meningkatkan kepercayaan investor untuk menanamkan modalnya pada perusahaan tersebut.

Salah satu jenis perusahaan yang menerbitkan sahamnya di Bursa Efek Indonesia (BEI) untuk mendapatkan dana adalah perusahaan sektor farmasi. Total perusahaan farmasi yang dikategorikan ke dalam sub kategori pada sektor Consumer Goods Industry oleh BEI pada tahun 2019 sekitar 9 perusahaan. Dalam kondisi naik turunnya perekonomian, salah satu sektor atau beberapa yang dapat mempertahankan diri salah satunya adalah industri farmasi. Industri manufaktur farmasi di Indonesia merupakan perusahaan yang memproduksi obat-obatan dimana pada saat kondisi yang sangat minim atau berkekurangan, setidaknya orang akan tetap berupaya memenuhi kesehatannya. Di samping itu adanya perluasan jangkauan Jaminan Kesehatan Nasional (JKN) dan semakin banyaknya RS baru yang berdiri sangat berpengaruh juga terhadap pertumbuhan sektor farmasi.

Maka dari itu, industri farmasi di Indonesia sangat diminati oleh para investor. Penelitian ini mengambil industri farmasi pada Bursa Efek Indonesia untuk diteliti, karena perusahaan farmasi merupakan perusahaan yang berada pada sektor bisnis yang strategis dan mempunyai perputaran bisnis yang sangat tinggi.

Penelitian ini bertujuan untuk menganalisis pengaruh Return On Assets (ROA), Return On Equity (ROE), Net Profit Margin (NPM) baik secara parsial 
P-ISSN 2580 - 7781

E-ISSN $2615-3238$

maupun secara simultan terhadap Harga Saham pada perusahaan Farmasi yang terdaftar di BEI.

\section{METODOLOGI PENELITIAN}

Populasi adalah wilayah generalisasi yang terdiri atas; obyek/subyek mempunyai kuantitas dan karakteristik tertentu yang ditetapkan oleh peneliti untuk dipelajari dan kemudian ditarik kesimpulannya (Sugiyono, 2003). Populasi dalam penelitian ini adalah seluruh perusahaan farmasi yang terdaftar di Bursa Efek Indonesia periode 2015-2019. Sample merupakan sebagian dari populasi suatu penelitian (Arikunto, 2006). Teknik pengambilan sampel pada penelitian ini dengan menggunakan metode purposive sampling, yakni teknik pengambilan sampel atas pertimbangan tertentu yaitu: saham perusahaan farmasi aktif diperdagangkan di Bursa Efek Indonesia pada periode tahun yang diteliti (tahun 2015-2019).

Data yang digunakan dalam laporan ini merupakan data Laporan Keuangan yang telah dipublikasikan melalui Bursa Efek Indonesia (BEI) dengan situs http://www.idx.co.id. Data tersebut dilakukan analisis menggunakan Regresi Linear Berganda dengan persamaan regresinya adalah sebagai berikut:

$$
\mathrm{Y}=\mathrm{a}+\mathrm{b}_{1} \mathrm{X}_{1}+\mathrm{b}_{2} \mathrm{X}_{2}+\mathrm{b}_{3} \mathrm{X}_{3}
$$

Keterangan :

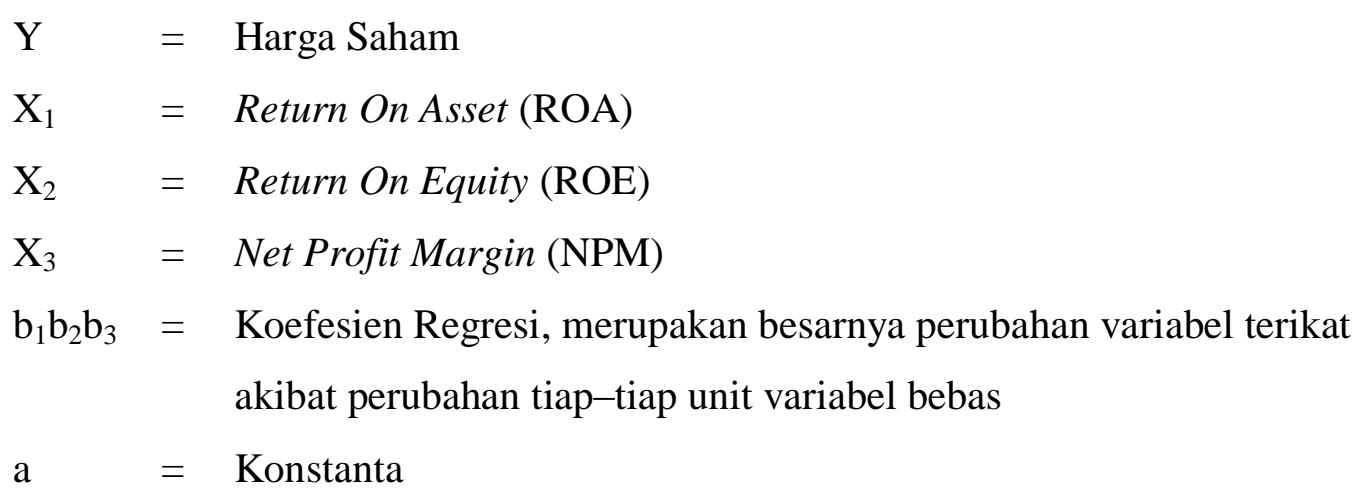

\section{HASIL PENELITIAN DAN PEMBAHASAN}

\section{Analisis Regresi Berganda}

Analisis regresi digunakan untuk mendapatkan pengaruh variabel-variabel bebas X1 (ROA), X2 (ROE), dan X3 (NPM) terhadap variabel Y (Harga Saham). 
Dalam pengolahan data dengan menggunakan analisis regresi linier berganda, dilakukan beberapa tahapan untuk mencari pengaruh antara variabel independen terhadap dependen. Berdasarkan hasil pengolahan data didapatkan ringkasan seperti berikut :

Tabel 1. Hasil Analisis Regresi Linier Berganda

\begin{tabular}{cc}
\hline Variabel & $\boldsymbol{B}$ \\
\hline Konstanta & 5.786 \\
X1 (ROA) & $-0,211$ \\
X2 (ROE) & 0,025 \\
X3 (NPM) & 0,231 \\
\hline Sumber : Data Diolah &
\end{tabular}

Berdasarkan tabel di atas, diperoleh model regresi sebagai berikut:

$\ln \mathrm{Y}=5.786-0,211 \mathrm{X} 1+0,025 \mathrm{X} 2+0,231 \times 3+\mathrm{e}_{\mathrm{i}}$

Interpretasi persamaan regresi:

Variabel konstanta memiliki koefisien regresi sebesar 5.786 yang menunjukkan bahwa tanpa adanya pengaruh dari variabel bebas, maka variabel Y (harga saham) sudah meningkat sebesar 5.786. Variabel X1 (ROA) memiliki koefisien regresi sebesar -0,211 yang menunjukkan bahwa peningkatan 1 angka variabel X1 (ROA) dapat menurunkan variabel Y (harga saham) sebesar -0,211. Variabel X2 (ROE) memiliki koefisien regresi sebesar 0.025 yang menunjukkan bahwa peningkatan 1 angka variabel X2 (ROE) dapat meningkatkan variabel Y (harga saham) sebesar 0.025 Variabel X3 (NPM) memiliki koefisien regresi sebesar 0.231 yang menunjukkan bahwa peningkatan 1 angka variabel X3 (NPM) dapat meningkatkan variabel $\mathrm{Y}$ (harga saham) sebesar 0.231

\section{Uji Hipotesis}

\section{Uji t (Uji Parsial)}

Pengujian model regresi secara parsial digunakan untuk mengetahui apakah masing-masing variabel independen pembentuk model regresi secara individu memiliki pengaruh yang signifikan terhadap variabel dependen. 
Tabel 2. Hasil Analisis Uji t

\begin{tabular}{lccc}
\hline \multicolumn{1}{c}{ Variabel } & $\boldsymbol{B}$ & $\mathbf{t}_{\text {hitung }}$ & Sig \\
\hline Konstanta & 5.786 & & \\
X1 (ROA) & $-0,211$ & $-2,988$ & 0.007 \\
X2 (ROE) & 0,025 & 3,722 & 0.001 \\
X3 (NPM) & 0,231 & 3,198 & 0.004 \\
\hline
\end{tabular}

Sumber: Data diolah

Berdasarkan tabel diatas didapatkan hasil bahwa variabel X1 (ROA) berpengaruh negatif dan signifikan terhadap variabel Y (harga saham). Terlihat dari statisitik uji t dengan |t hitung| lebih besar dari t tabel $(-2.988>1,721)$ dan nilai p-value $\mathrm{t}$ yang lebih kecil dari $\alpha(0,007<0,050)$, variabel $\mathrm{X} 2$ (ROE) berpengaruh positif dan signifikan terhadap variabel $\mathrm{Y}$ (harga saham). Terlihat dari statisitik uji t dengan |t hitung| lebih besar dari t tabel $(3.722>1.721)$ dan nilai p-value $\mathrm{t}$ yang lebih kecil dari $\alpha(0.001<0.050)$, Variabel X3 (NPM) berpengaruh positif dan signifikan terhadap variabel $\mathrm{Y}$ (harga saham). Terlihat dari statisitik uji t dengan |t hitung| lebih besar dari t tabel $(3.198>1.721)$ dan nilai p-value t yang lebih kecil dari $\alpha(0.004<0.050)$.

\section{Uji F (Uji Simultan)}

Uji F digunakan untuk menguji apakah variabel - variabel independen secara bersama - bersama signifikan berpengaruh terhadap variabel dependen.

\begin{tabular}{lcc}
\multicolumn{3}{c}{ Tabel 3. Hasil Analisis Uji F } \\
\hline \multicolumn{1}{c}{ Variabel } & F $_{\text {hitung }}$ & Sig \\
\hline $\begin{array}{l}\text { X1 (ROA), X2 (ROE) X3 } \\
\text { (NPM) }\end{array}$ & 6.979 & 0.002 \\
\hline
\end{tabular}

Sumber : Data diolah

Berdasarkan tabel di atas dapat dilihat bahwa diperoleh nilai $\mathrm{F}$ hitung lebih besar dari F tabel $(6.979$ > 3.072) dan memiliki nilai p-value yang lebih kecil dari $\alpha(0.002<0.050)$, sehingga $\mathbf{H}_{\mathbf{0}}$ ditolak dan $\mathbf{H}_{\mathbf{1}}$ diterima. Artinya bahwa secara simultan/serentak, variabel bebas yaitu X1 (ROA), X2 (ROE), dan X3 (NPM) berpengaruh secara signifikan terhadap variabel Y (harga saham). 
P-ISSN $2580-7781$

E-ISSN $2615-3238$

\section{Koefisien Determinasi $\left(\mathbf{R}^{2}\right)$}

Tabel 4. Hasil Uji Koefisien Determinasi

\begin{tabular}{ccc}
\hline Model & $\mathrm{R}$ & R Square \\
\hline 1 &, $707^{\mathrm{a}}$ &, 499 \\
\hline
\end{tabular}

Sumber : Data diolah

Besarnya kontribusi pengaruh dari variabel independen secara simultan terhadap variabel dependen, berdasarkan hasil perhitungan pada Tabel 4 dengan nilai koefisien determinasi (R Square) sebesar 0.499. Hasil tersebut menjelaskan sumbangan atau kontribusi pengaruh dari variabel-variabel bebas ( X1 (ROA), X2 (ROE), dan X3 (NPM)) yang disertakan dalam persamaan regresi terhadap variabel Y (harga saham) adalah sebesar 49,9\%, sedangkan 50,1\% lainnya disumbangkan oleh variabel bebas lainnya yang tidak dimasukkan ke dalam persamaan ini.

\section{PEMBAHASAN}

Pengaruh Return on Assets (ROA) terhadap Harga Saham pada Persahaan Farmasi

Hasil penelitian menunjukkan bahwa variable Return On Asset (ROA) berpengaruh negatif signifikan terhadap Harga Saham pada perusahaan Farmasi yang terdaftar di Bursa Efek Indonesia (BEI) tahun 2015-2019. Hal ini menjelaskan bahwa adanya pengaruh yang negatif menunjukkan bahwa Return On Asset memiliki hubungan yang tidak searah terhadap return saham, dimana jika Return On Asset naik maka return sahamnya turun, hal ini disebabkan oleh beberapa faktor antara nilai kurs rupiah terhadap mata uang asing anjlok, inflasi, dan manipulasi pasar seperti rumor, berita bahkan sekedar isu yang entah darimana sumbernya bisa berpengaruh terhadap kenaikan atau penurunan harga saham.

Pada penelitian ini menunjukkan bahwa Return On Assets perusahaan sektor farmasi di Bursa Efek Indonesia mengalami kenaikan tetapi tidak direspon positif oleh investor sehingga nilai saham mengalami penurunan dan berdampak pada harga saham, 
P-ISSN 2580 - 7781

E-ISSN 2615 - 3238

\section{Pengaruh Return On Equity (ROE) terhadap Harga Saham pada Perusahaan}

\section{Farmasi}

Hasil pengujian hipotesis menunjukkan bahwa variable Return On Equity (ROE) berpengaruh signifikan terhadap harga saham pada perusahaan farmasi yang terdaftar di Bursa Efek Indonesia tahun 2015-2019. Hal ini menjelaskan bahwa perubahan ROE mempengaruhi secara menyeluruh terhadap harga saham.

Return On Equity (ROE) merupakan rasio untuk mengukur efisiensi perusahaan dalam menghasilkan laba melalui ekuitas (modal sendiri) yang dimilikinya. Bagi para pemegang saham semakin tinggi rasio ini maka akan semakin baik karena memberikan tingkat pengembalian yang lebih besar untuk pemegang saham.

Pada penelitian ini menunjukkan bahwa Return on Equity (ROE) berpengaruh positif dan signifikan terhadap harga saham. Dapat dikatakan bahwa nilai ROE pada perusahaan farmasi selaras dengan pergerakan harga saham dimana ketika nilai ROE meningkat harga saham juga ikut meningkat. Semakin tinggi ROE akan mencerminkan efektifitas laba dari modal perusahaan itu sendiri, hal ini menyebabkan investor semakin percaya untuk berinvestasi saham pada perusahaan yang memiliki nilai ROE yang tinggi. Ketika investor berbondongbondong untuk berinvestasi, mengakibatkan harga saham perusahaan akan mengalami peningkatan.

\section{Pengaruh Net Profi Margin (NPM) terhadap Harga Saham pada Perusahaan Farmasi}

Pada penelitian ini menunjukkan bahwa memiliki pengaruh yang positif terhadap harga saham. NPM adalah kelompok rasio profitabilitas yang digunakan untuk mengukur kemampuan perusahaan dalam memperoleh laba bersih dari penjualan yang dilakukan. Pengaruh positif dan signifikan terhadap harga saham yang ditemukan dalam penelitian ini menunjukkan bahwa perusahaan tersebut berhasil memperoleh laba bersih dan mengefisiensikan biaya-biaya yang berhubungan dengan kegiatan operasionalnya. Kondisi yang demikian menjadi salah satu faktor para investor dalam menentukan perusahaan mana yang 
P-ISSN $2580-7781$

E-ISSN $2615-3238$

sahamnya dapat memberikan prospek kepada mereka para investor atau mampu meningkatkan kepercayaan para investor tersebut untuk menanamkan modalnya.

\section{KESIMPULAN}

Berdasarkan hasil penelitian, dapat disimpulkan bahwa secara parsial maupun secara simultan, variabel Return On Assets (ROA), Return On Equity (ROE), dan Net Profit Margin (NPM) berpengaruh terhadap harga saham pada perusahaan farmasi yang terdaftar di Bursa Efek Indonesia periode 2015-2019. Sementara itu berdasarkan koefisien determinasi, disimpulkan bahwa harga saham ditentukan oleh variabel-variabel bebas ( X1 (ROA), X2 (ROE), dan X3 (NPM)) yang disertakan dalam persamaan regresi adalah sebesar $49,9 \%$, sedangkan $50,1 \%$ lainnya disumbangkan oleh variabel bebas lainnya yang tidak masuk dalam penelitian ini

\section{DAFTAR PUSTAKA}

Arikunto, S. 2006. Metode penelitian kualitatif. Jakarta: Bumi Aksara.

Darmadji, T., \& Fakhruddin, H. M. 2011. Pasar modal di Indonesia pendekatan dan tanya jawab Edisi Ke-3: Salemba Empat. Jakarta.

Fahmi, I. 2012. Analisis Kinerja Keuangan: Panduan bagi Akademisi, Manajer, dan Investor untuk Menilai dan Menganalisis Bisnis dari Aspek Keuangan.

Hanafi, M. M., \& Halim, A. 2012. Analisis Laporan Keuangan, Edisi Keempat. Yogyakarta: UPP STIM YKPN.

Lukman, S. 2009. Manajemen Keuangan Perusahaan Konsep Aplikasi Dalam Perencanaan, Pengawasan dan Pengambilan Keputusan (Edisi Baru) Jakarta: Garfindo Persada.

Sugiyono, R. 2003. Metode Penelitian Survey. Jakarta : LP3ES. 